\title{
UNIVERSITY OF CAMBRIDGE NATURAL RADIOCARBON MEASUREMENTS XIII
}

\author{
V R SWITSUR and R G WEST
}

\author{
Sub-department of Quaternary Research, \\ 5 Salisbury Villas, Station Road, Cambridge, England
}

The dates presented here were calculated from measurements made at the University Radiocarbon Dating Research Laboratory mostly during 1973-74. The radioactivity of the samples was counted in gas proportional detectors, either silica lined (de Vries et al, 1959) or of pure copper, filled to 2 atmospheres pressure with pure carbon dioxide. The detectors were fixed in, and completely surrounded by, a plastic scintillator anticoincidence shield mounted inside a massive lead shield to protect against environmental radiation (Switsur, Hall and West, 1970). Modern sample gas was obtained from the combustion of AD 1845 to 1855 rings of an oak tree grown near Cambridge and felled in 1950. Background samples were prepared from Welsh anthracite. The contemporary sample was frequently compared with the activity of the NBS oxalic acid international standard. Age calculations were based on the ${ }^{14} \mathrm{C}$ half-life of 5568 years and the uncertainty stated as one standard deviation calculated from the statistical analyses of sample and standards counting rates.

Oxidation of the samples was performed in high pressure oxygen in a 'bomb' combustion unit (Switsur et al, 1970; Switsur, 1972; Switsur and West, 1973) followed by purification of the carbon dioxide produced. The technique was modified slightly for samples such as limnic mud deposits or gyttja which often contain excessive electronegative impurities and require more extensive purification than wood or charcoal samples. For these, a vessel containing either sodium hydroxide or ammonium hydroxide solution was placed in the combustion chamber. The carbon dioxide and acidic impurities evolved were absorbed in this as the oxidation progressed. Within a few minutes of igniting the specimen in the chamber the reaction was complete, as indicated by the fall in chamber pressure, and the excess oxygen was released. The carbon of the sample was thus converted to a carbonate solution. Initial purification of this was by precipitation as barium carbonate followed by thorough washing. Carbon dioxide was liberated with either hydrochloric or phosphoric acid and further purified suitably for the proportional counters.

As previously we have concentrated largely on determinations for our own studies with members of the Sub-department of Quaternary Research, Univ Cambridge and with archaeologists from Cambridge and other institutions.

\section{ACKNOWLEDGMENTS}

We wish to thank Alan Ward and Chris Devine for their conscientious work in the Research Laboratory. We appreciate the continued 
interest and support of Sir Harry Godwin. We express our thanks to the Science Research Council and the National Environmental Research Council for financial support in establishing the laboratory.

\section{SAMPLE DESGRIPTIONS}

\section{GEOLOGIC SAMPLES}

A. British Isles

\section{Scottish Tree Stump series}

This continues the study of the stratigraphy of horizons of tree stumps commonly found in Scottish peat bogs ( $R$, 1970, v 12, p 594-596). Samples coll 1966 from 3 main areas, the NW Highlands, the Cairngorm area of the E Grampians and the Galloway Hills of SW Scotland for pollen analysis by $\mathrm{H} \mathrm{H}$ Birks and radiocarbon analysis by $\mathrm{V} R$ Switsur, both of Univ Cambridge.

\section{North West Highland area}

Q-1150. Kinlochewe, Pine, $50 \mathrm{~cm}$

$4447 \pm 100$

2497 BC

Wood of Pinus Silvestris stump from 45 to $50 \mathrm{~cm}$ below surface of blanket bog peat from sec exposed in ditch to base of bog, depth $125 \mathrm{~cm}$. Site $1 \mathrm{~km}$ NW Kinlochewe, Wester Ross $\left(57^{\circ} 36^{\prime} \mathrm{N}, 5^{\circ} 19^{\prime} \mathrm{W}\right.$, Nat Grid Ref 28/021628). Age is that of upper of 2 pine stump layers which were not traceable over a large area. Probably corresponds to site of Durno and McVean (1959) who carried out pollen analyses.

Q-1151. Kinlochewe, Pine, $80 \mathrm{~cm}$

$4671 \pm 80$

Wood of Pinus Silvestris stump from 70 to $80 \mathrm{~cm}$ below surface as in Q-1150.

\section{Q-1152. Kinlochewe, Birch, 105cm}

$6974 \pm 120$

Twigs (Betula) from layer 95 to $105 \mathrm{~cm}$ below peat surface of site of Q-1150. These date onset of peat growth at site. With pollen diagrams of Durno \& McVean, will aid correlating vegetational changes in area with other parts of Scotland.

\section{Q-1153. Beinn Dearg, Pine, $140 \mathrm{~cm}$}

Wood (Pinus) from layer 130 to $140 \mathrm{~cm}$ below surface of blanket bog in deep haggs completely exposing sec to base at $190 \mathrm{~cm}$ on exposed col. Site on S slope of Beinn Dearg, Dirremor, Ullapool, Wester Ross $\left(57^{\circ} 45^{\prime} \mathrm{N}, 4^{\circ} 55^{\prime} \mathrm{W}\right.$, Nat Grid Ref 28/265775). No pollen analyses as yet.

Q-1154. Beinn Dearg, Birch, $185 \mathrm{~cm}$

$$
5885 \pm 110
$$

Wood (Betula) from layer 180 to $185 \mathrm{~cm}$ below surface of site of Q-1153. Dates onset of peat growth at site. Pollen analyses to be done. 
Q-1155. Inchnadamph, Pine, $90 \mathrm{~cm}$

Wood (Pinus Silvestris) from stump 70 to $90 \mathrm{~cm}$ below surface of peat in sec exposed in peat haggs. Profile, obtained from Hiller peat borer, showed degraded $\mathrm{W}$ blanket bog containing pine at 70 to $90 \mathrm{~cm}$ and birch at 225 to $250 \mathrm{~cm}$. Underlying was Eriophorum Vaginatum peat to $275 \mathrm{~cm}$ and fibrous, little humified peat to base at $285 \mathrm{~cm}$. Site is on $\mathrm{N}$ side of $\mathrm{R}$ Loanan, $5 \mathrm{~km} \mathrm{~S}$ of Inchnadamph, W Sutherland $\left(58^{\circ} 8^{\prime} \mathrm{N}, 4^{\circ} 58^{\prime} \mathrm{W}\right.$, Nat Grid Ref $\left.29 / 243186\right)$ and was studied by Lewis (1907). Pollen analyses to be done.

\section{Q-1156. Rogart, Pine, $50 \mathrm{~cm}$}

$3976 \pm 100$

Wood (Pinus Silvestris) from layer 30 to $50 \mathrm{~cm}$ below present surface of bog exposed by peat cutting. Sample obtained by Hiller peat borer and core showed 2 further wood (unid) layers at 130 to $140 \mathrm{~cm}$ and 170 to $180 \mathrm{~cm}$ and then Phragmites/Sphagnum peat with Betula remains to base at $395 \mathrm{~cm}$. Site on open moorland $5 \mathrm{~km} \mathrm{~N}$ of Rogart, Strathfleet, E Sutherland (58 $2^{\prime}$ N, $4^{\circ} 10^{\prime} \mathrm{W}$, Nat Grid Ref 29/735068). See Lewis (1911).

\section{Q-1157. Rannoch Moor, Pine, 75cm}

Wood (Pinus Silvestris) from stump 60 to $75 \mathrm{~cm}$ below peat surface from sec exposed in peat hagg. Site on NW corner of Rannoch Moor, Argyll (56 $38^{\circ} \mathrm{N}, 4^{\circ} 50^{\prime} \mathrm{W}$, Nat Grid Ref 27/275535). One of several well-marked layers of pine remains seen widely on Rannoch Moor. See Lewis (1907). Pollen analyses to be made.

\section{Q-1158. Rannoch Moor, Pine, $100 \mathrm{~cm}$}

$6139 \pm 110$

Twigs (Pinus Silvestris) from layer 95 to $100 \mathrm{~cm}$ below surface of peat of site of Q-1157. Dates extermination of trees by further peat growth. Pollen analyses to be made.

\section{Q-1149. Loch Morar, Birch, $90 \mathrm{~cm}$}

$1547 \pm 50$

Branch of Betula wood from layer 80 to $90 \mathrm{~cm}$ below present peat surface exposed by peat cutting, on $\mathrm{N}$ side of Loch Morar, $\mathrm{W}$ Inverness, near to Morar Lodge ( $56^{\circ} 58^{\prime} \mathrm{N}, 5^{\circ} 46^{\prime} \mathrm{W}$, Nat Grid Ref 17/700930). Hiller borer showed no further timber layer but coarse Carex fen peat with wood fragments to base at $160 \mathrm{~cm}$. Date indicates that tree growth in this area occurred much later than in other areas studied. Pollen analysis to be made.

\section{Q-1123. Loch Morar Birch branch}

$1530 \pm 50$ AD 420

Check sample on birch branch from 80 to $90 \mathrm{~cm}$ at Loch Morar, see Q-1149. Confirms sample as latest found in study of tree layers. 


\section{Galloway area}

Q-872. Cooran Lane, $105 \mathrm{~cm}$

Peat from depth 100 to $105 \mathrm{~cm}$ in blanket bog, alt $260 \mathrm{~m}\left(55^{\circ} 7^{\prime} \mathrm{N}\right.$, $4^{\circ} 23^{\prime} \mathrm{W}$, Nat Grid Ref 25/480843), overlying pine stump Q-871 dated at 7471 BP. Pollen analysis indicated transition between Zones VI and VIIa.

Q-1148. Cooran Lane, $115 \mathrm{~cm}$

$5912 \pm 100$

$3962 \mathrm{BC}$

Wood peat from a band between 110 to $115 \mathrm{~cm}$ below surface of bog, apparently assoc with roots of stump Q-871 (R, 1970, v 12, p 595).

Q-875. Cooran Lane Pine, Site B

$6564 \pm 120$

Wood stump (Pinus Silvestris) lying in a similar position to stump of sample Q-871.

Q-879. Clatteringshaws Loch, $100 \mathrm{~cm}$

$4815 \pm 80$

2865 BC

Amorphous blanket bog peat from 95 to $100 \mathrm{~cm}$ below surface $\left(55^{\circ} 4^{\prime} \mathrm{N}, 4^{\circ} 17^{\prime} \mathrm{W}\right.$, Nat Grid Ref 25/5477) at level of pine pollen maximum in assoc diagram.

Q-880. Clatteringshaws Loch, base

$6820 \pm 180$

$4870 \mathrm{BC}$

Fen wood peat from 185 to $190 \mathrm{~cm}$, base of the profile. Dates onset of peat growth on former mineral soil due to increased moisture of the habitat.

General Comment: these samples are from 13 different sites (see also $\mathrm{R}, 1970, \mathrm{v} 12, \mathrm{p}$ 594-596) and are representative of the areas studied. Radiocarbon dates indicate that conditions were suitable for tree growth on at least one site throughout most of the period from 4000 to 7500 BP, except perhaps between ca 5250 to 5750 BP from which period no samples have yet been dated. The temporal distribution is not uniform and the tree dates exhibit a bimodal character with maxima ca 4000 to $4500 \mathrm{BP}$ and ca 6500 to $7500 \mathrm{BP}$. These maxima appear to have regional rather than climatic connotations (Birks \& Switsur, mss in preparation).

\section{Q-1121. A Mhoine}

$4393 \pm 50$

Wood (Pinus Silvestris) (58 $38^{\prime}$ N, $4^{\circ} 36^{\prime}$ W, Nat Grid Ref 29/ 487605 ) from stump underlying $30 \mathrm{~cm}$ eroded surface of peat at A Mhoine, $1.5 \mathrm{~km}$ E of Loch Hope, Sutherland, Scotland. Alt $142 \mathrm{~m}$ above mean sea level. Coll Aug, 1972 by H H Lamb, Climatic Research Unit, Univ East Anglia. First sample of tree remains from woodland formerly growing in $\mathrm{N}$ coast area to be dated. Comment: woodland in area today is confined to few localities in valleys sheltered from winds. Confusing 
descriptions suggest some areas were wooded in times of the Viking earls of Orkney and later. Date agrees with others from $\mathrm{N}$ part of $\mathrm{W}$ coast at Loch Broom, Loch Sionascaig and Duartbeg where last forests close to the coast were ca $4000 \mathrm{yr}$ ago. Of interest in interpretation of meteorology of warmest postglacial times.

\section{Q-1120. Colney Street}

$14,320 \pm 210$

Detritus mud with plant fragments, beetle remains and shell (mollusk) fragments erratically distributed in layer of coarse to medium gravel and sand $5.5 \mathrm{~m}$ thick resting on gray shelly clay (Tertiary) in $\mathrm{S}$ face of Colney Street quarry, St Alban's Hertfordshire $\left(51^{\circ} 42^{\prime} \mathrm{N}, 0^{\circ}\right.$ $20^{\prime} \mathrm{W}$, Nat Grid Ref TL/152017). Coll Nov 1971 by P L Gibbard, Sub-dept Quaternary Research, Univ Cambridge. Comment: dates aggradation of low terrace gravels of $\mathrm{R}$ Colne and, hence Weichselian history of immediate area; see Godwin (1964) for discussion of similar deposits.

\section{Q-1171. Glenshieldaig, Wester Ross}

$1230 \pm 40$

(Cyperaceae-Sphagnum) peat from 30 to $32 \mathrm{~cm}$ below surface of bog (57 $28^{\prime} \mathrm{N}$, $5^{\circ} 36^{\prime} \mathrm{W}$, Nat Grid Ref NG/844484) Glenshieldaig, Wester Ross, Scotland. Coll April 1973 by J A Lee; subm by J H Tallis, Dept Botany, Univ Manchester. Comment (JHT): Glenshieldaig profile is one of series of peat profiles analyzed for lead content as part of study into changes of lead pollution in recent centuries in the British Isles. Glenshieldaig is far from any known source of atmospheric lead pollution and has over all low lead content. Significant rises in lead levels appear at depths $8 \mathrm{~cm}$ and $21 \mathrm{~cm}$ below present day surface, which, through pollen analyses, historical records, and radiocarbon date may be dated as ca $\mathrm{AD} 1650$ and ca $\mathrm{AD}$ 1150, respectively (Lee \& Tallis, in press.)

\section{Hatchmere series}

Mud samples, forming part of study of vegetational history at Hatchmere, Cheshire $\left(53^{\circ} 14^{\prime} \mathrm{N}, 2^{\circ} 41^{\prime} \mathrm{W}\right.$, Nat Grid Ref $\left.33 / 554723\right)$ by H J B Birks and J E Young, Sub-dept Quaternary Research, Univ Cambridge. Samples are from floor of postglacial lake taken as a $7.5 \mathrm{~cm}$ diam core with a square rod piston sampler. Cores were extruded 3 days after colln, wrapped in Alcan wrap, foil, and polythene and stored at $15^{\circ} \mathrm{C}$ for nearly a year until sampled for radiocarbon dating June 1973. Samples taken with reference to pollen analysis curve at zone boundaries to calculate sediment accumulation rates and absolute pollen influx rates. Samples id by depth in pollen diagram.

\section{Q-1159. Hatchmere, 722.5 to $727.5 \mathrm{~cm}$}

$7403 \pm 114$

Lake mud from 722.5 to $727.5 \mathrm{~cm}$, level in pollen diagram at which frequencies of Alnus pollen rise. 
Q-1160. Hatchmere, 772.5 to $777.5 \mathrm{~cm} \quad 6390 \mathrm{BC}$

Lake mud from 772.5 to $777.5 \mathrm{~cm}$, level in pollen diagram at which Pinus pollen frequencies reach their maximum.

\section{Q-1161. Hatchmere, 802.5 to $807.5 \mathrm{~cm}$}

$8776 \pm 130$

$6826 \mathrm{BC}$

Lake mud from 802.5 to $807.5 \mathrm{~cm}$, level in pollen diagram at which Quercus pollen frequencies increase.

\section{Q-1162. Hatchmere, 842.5 to $847.5 \mathrm{~cm}$}

$9679 \pm 140$

Lake mud from 842.5 to $847.5 \mathrm{~cm}$, level in pollen diagram at which frequencies of Corylus pollen rise.

General Comment: 1st 4 dates from site agree with dates for comparable pollen analytical boundaries at nearby Red Moss (Hibbert, Switsur, \& West, 1971), eg, Q-917 (7460 \pm 150$)$ and Q-1159 (7403 \pm 114$)$ for the beginning of the Alnus pollen curve, Q-920 (8790 \pm 170$)$ and Q-1161 $(8776 \pm 130)$ for rise in Quercus. Sedimentation rate as calculated from these 4 dates is very constant at $5.4 \mathrm{~cm} /$ (radiocarbon) century, but more dates are needed before reliable sedimentation accumulation rates may be calculated to allow conversion of pollen concentration figures to absolute pollen influx rates.

\section{North Knapdale, Argyll series}

This series is part of a study in conjunction with L Rymer, Subdept Quaternary Research, Univ Cambridge, of the effect of Man on the landscape of North Knapdale, Argyll, Scotland. Three cores were taken, using a $7.5 \mathrm{~cm}$ diam Livingstone piston corer, at sites within the parish. Core from Drimnagall, not fully examined, appears to have a complete late-glacial sequence. Two cores were taken from the Taynish peninsula. One was an open water core from Lochan Taynish, the other was from the fen at $S$ end of lochan. Absolute pollen analyses from cores are being made and dates required for pollen influx calculations via sedimentation rates. Oak woods on peninsula seem to be sub-natural, and pollen diagram shows little change, with all taxa still present in the area. Samples coll Jan 1972 by L Rymer from Taynish Fen $\left(56^{\circ}\right.$ $5^{\prime} \mathrm{N}, 5^{\circ} 40^{\prime} \mathrm{W}$, Nat Grid Ref $\left.16 / 738854\right)$ and Lochan Taynish $\left(56^{\circ} 5^{\prime}\right.$ N, $5^{\circ} 40^{\prime}$ W, Nat Grid Ref 16/738855).

\section{Q-1179. Taynish Fen, LTF 805-815}

$7086 \pm 85$

Fen peat from 805 to $815 \mathrm{~cm}$.

Q-1180. Taynish Fen, LTF 730-740

$6070 \pm 120$

Fen peat from 730 to $740 \mathrm{~cm}$, pollen curves indicate region of Elm decline, but frequency change is small. 
Q-1181. Taynish Fen, LTF 620-630

$4665 \pm 115$

Fen peat from 620 to $630 \mathrm{~cm}$.

2715 BC

Q-1182. Taynish Fen, LTF 405-415

$2446 \pm 80$

Fen peat from 405 to $415 \mathrm{~cm}$.

$496 \mathrm{BC}$

\section{Q-1183. Lochan Taynish, LTW 331-351}

$4314 \pm 75$

$2364 \mathrm{BC}$

Lake mud from 331 to $351 \mathrm{~cm}$ below sediment level at center of lake beneath $425 \mathrm{~cm}$ water.

Q-1184. Lochan Taynish, LTW 151-171

$1961 \pm 75$

Lake mud of low organic content from 151 to $171 \mathrm{~cm}$ below sediment surface.

General Comment: dates are internally consistent but difficult to correlate by stratigraphic means and pollen diagram which show little change and are not easily divisible into definitely recognizable pollen assemblage zones. Further correlation will be attempted based on radiocarbon dates.

\section{Pedogenic Carbonate series}

\section{B. India}

The pedogenic carbonate in the buried soils studied is derived predominantly from atmospheric carbon dioxide activity during soil formation so that radiocarbon concentration in a stratum reflects its time of deposition.

Buried soil of late Quaternary alluvium in Giujarat State, W India is prominently exposed in the valleys of the Narmada, Mahi and Sabarmati rivers, which cross the plain of Giujarat, cutting 30 to $40 \mathrm{~m}$ deep, exposing the stratigraphy. A red-brown band, 3 to $4 \mathrm{~m}$ deep, 10 to $12 \mathrm{~m}$ below the surface of the plain, runs for $>100 \mathrm{~km}$. This soil contains the pedogenic carbonate, a product of weathering of the silt in situ. For a discussion of suitability of calcium carbonate nodules for dating see Hegde \& Switsur (1973). Dating of soil carbonate is described by Rightmire (1967), Rafter (1970), Williams \& Polach (1971) and Leamy \& Rafter (1972).

Samples coll 1972 by K T M Hegde, M S Univ Baroda, from selected segments of the river valleys. Sites were close to villages named. Series of soil samples taken $20 \mathrm{~cm}$ in from scraped surface at $20 \mathrm{~cm}$ intervals, for chemical analysis. Those with maximum carbonate concentration were dated by V R Switsur.

Q-1104. Dhegam

$22,450 \pm 550$

On the Narmada R $\left(73^{\circ} 07^{\prime} \mathrm{N}, 21^{\circ} 46^{\prime} \mathrm{E}\right)$.

\section{0,500 BC}


Q-1105. Nikora

Modern

On the Narmada R $\left(73^{\circ} 09^{\prime} \mathrm{N}, 21^{\circ} 48^{\prime} \mathrm{E}\right)$.

$21,600 \pm 500$

Q-1106. Lilod

$19,650 \mathrm{BC}$

On the Narmada $\mathrm{R}\left(73^{\circ} 14^{\prime} \mathrm{N}, 21^{\circ} 52^{\prime} \mathrm{E}\right)$.

Q-1107. Deroli

$24,500 \pm 700$

On the Narmada R $\left(73^{\circ} 14^{\prime} \mathrm{N}, 21^{\circ} 55^{\prime} \mathrm{E}\right)$.

$22,550 \mathrm{BC}$

Q-1108. Sinor

$17,400 \pm 500$

15,450 BC

On the Narmada R $\left(73^{\circ} 20^{\prime} \mathrm{N}, 21^{\circ} 54^{\prime} \mathrm{E}\right)$.

$22,600 \pm 550$

Q-1109. Dabka

$20,650 \mathrm{BC}$

On the Mahi R $\left(72^{\circ} 56^{\prime} \mathrm{N}, 22^{\circ} 15^{\prime} \mathrm{E}\right)$.

$18,250 \pm 400$

Q-1110. Vasad

On the Mahi $\mathrm{R}\left(73^{\circ} 07^{\prime} \mathrm{N}, 22^{\circ} 28^{\prime} \mathrm{E}\right)$.

$16,300 \mathrm{BC}$

Q-1111. Ahima

$22,150 \pm 600$

$20,200 \mathrm{BC}$

On the Mahi R $\left(73^{\circ} 12^{\prime} \mathrm{N}, 22^{\circ} 36^{\prime} \mathrm{E}\right)$.

$20,400 \pm 550$

Q 1112. Pethapura

18,450 BC

On the Sabarmathi R $\left(72^{\circ} 41^{\prime} \mathrm{N}, 23^{\circ} 16^{\prime} \mathrm{E}\right)$.

$21,500 \pm 500$

Q-1113. Hirpura

$19,550 \mathrm{BC}$

On the Sabarmathi $\mathrm{R}\left(72^{\circ} 50^{\prime} \mathrm{N}, 23^{\circ} 11^{\prime} \mathrm{E}\right)$.

General Comment: dates are later than expected and indicate approx formation time of the buried soil (except anomalous, unexplained value of Q-1105) which is representative of Quaternary alluvial stratigraphy across the Indian Sub-Continent. Dates require careful study in terms of the geochemical process proposed for carbonate formation and effect of subsequent leaching of the deposits and reprecipitation, before they should be applied to apparently assoc stone age industries, for which they might provide a useful temporal reference; see Wainwright (1964).

\section{Lake Shala, Ethiopia series}

$$
\text { C. Africa }
$$

Part of a study of late Quaternary lake levels in the rift valley of S Ethiopia by A T Grove, Dept Geog, Univ Cambridge. During the past $10 \mathrm{yr}$ we have learned that the high levels of the Galla lakes system were probably connected and the single large lake overflowed $\mathrm{N}$ into the $\mathrm{R}$ Awash valley. Horizontal beaches developed at different levels, the most important at $119 \mathrm{~m}$ above Lake Shala $\left(7^{\circ} 30^{\prime} \mathrm{N}, 38^{\circ} 40^{\prime} \mathrm{E}\right)$. Shells (Melanoides Tuberculata), (Bulinus) were coll by A T Grove, id by B W Sparks, Univ Cambridge. 
Q-1101. Lake Shala, 3

Sample underlay calcrete $1 \mathrm{~m}$ thick in sec alongside new road Mojjo to Shashamane; alt $93 \mathrm{~m}$ above Lake Shala, a high shoreline of the lake.

Q-1114. Lake Shala, 6

$8320 \pm 175$

Sample from shell layer $20 \mathrm{~cm}$ thick under $1.5 \mathrm{~m}$ sand. Alt $87 \mathrm{~m}$ above Lake Shala, a former high shoreline of the lake.

General Comment: Q-1114 falls into expected range but Q-1101 is later than expected if present height above lake level is used as guide to age. Lake levels possibly fluctuated and remained as high as $90 \mathrm{~m}$ above present level as late as 6500 BP. For further work and dates on shorelines of E African lakes, see Grove \& Goudie (1971), Butzer et al (1972); Fontes et al (1973).

\section{ARCHAEOLOGIC SAMPLES}

\section{A. British Isles}

\section{Somerset Levels series, SW England}

Continuation of joint program of J M Coles, V R Switsur, and F A Hibbert in excavation, dating and stratigraphy of Somerset trackway complex. Coll July 1972 by J M Coles from Sweet Trackway Site ' $\mathrm{F}$ ' $\left(51^{\circ} 09^{\prime} \mathrm{N}, 2^{\circ} 50^{\prime} \mathrm{W}\right.$, Nat Grid Ref ST/422403), Shapwick Heath, Somerset.

Q-1102. Sweet Track, 957

$5140 \pm 100$

Peat immediately underlying trackway rails.

$3190 \mathrm{BC}$

\section{Q-1103. Sweet Track, 982}

$5103 \pm 100$

Peat from beneath planks of track but overlying rails.

General Comment: dated to relate precisely underlying peat surface and 1st stages of trackway construction. Dates confirm previous results for this track (Q-962, -963, -966, -968, and Q-991) as oldest known track in Britain and agree with stratigraphic position of trackways in the peat. Dates assoc Neolithic flints, pottery and wooden objects and aid study of peat growth rate (Coles et al, 1973).

\section{Q-1037. Burtle Bridge Track}

$4370 \pm 60$

Wood of trackway, overlying Q-1035 $\left(51^{\circ} 11^{\prime} \mathrm{N}, 2^{\circ} 52^{\prime} \mathrm{W}\right.$, Nat Grid Ref ST/393426). Coll 1971 by C F Clements from multilayer track beneath $65 \mathrm{~cm}$ peat.

\section{North Elmham, Norfolk series}

Continuation of study of North Elmham cistern whose construction was dated AD $831 \pm 20$ by combination of a series of 4 radiocarbon dates and tree ring measurements (Switsur \& West, 1973; Wade-Martins et al, 1973). Samples from infilling of cistern $\left(52^{\circ} 45^{\prime} \mathrm{N}, 0^{\circ} 56^{\prime} \mathrm{E}\right.$, Nat Grid 
Ref TF/987215), obtained during excavations by Peter Wade-Martins, Norfolk Archaeol Unit. Historically, site is known to have been abandoned $\mathrm{Ca}$ AD 840: radiocarbon dates help determine rate of infilling of shaft.

Q-1193. North Elmham, BB

$956 \pm 60$

Twigs of hazel, birch and oak from Layer BB at base of cistern shaft, $5.6 \mathrm{~m}$ below site datum.

Q-1194. North Elmham, AX

$917 \pm 60$

Twigs of unid wood from Layer AX near base of cistern shaft, $5.2 \mathrm{~m}$ below site datum.

Q-1195. North Elmham, AG, AK

$\begin{aligned} 904 & \pm 60 \\ \text { AD } 1046 & \end{aligned}$ datum.

Twigs of unid wood from Layers AG to AK, 4.1 to $4.6 \mathrm{~m}$ below site

General Comment: dates for infilling twigs are inseparable statistically and suggest that cistern may have been used for $11 / 2$ to 2 centuries before abandonment, when it rapidly was filled with detritus. After calibration by Bristlecone Pine curve the dates appear to be, on historical evidence, approx a century late.

\section{Mesolithic Project}

The following 8 dates are initial results in a project begun by $\mathrm{R} \mathrm{M}$ Jacobi and V R Switsur, both of Univ Cambridge, to study and date sites in the English Mesolithic. Sites range from Early to Late Mesolithic. Samples were accepted from several collectors but were very carefully selected; only those with a high probability of archaeol assoc with occupation sites were used. Contaminating substances that could have distorted results were removed by thorough physical and chemical pretreatment. This 1st series deals with sites in Pennine Range lying between $53^{\circ}$ to $54^{\circ} \mathrm{N}$.

\section{$5850 \pm 80$ \\ Q-788. March Hill, Marsden, Yorkshire 3900 BC}

Burnt wood ( $53^{\circ} 37^{\prime} \mathrm{N}, 1^{\circ} 58^{\prime} \mathrm{W}$, Nat Grid Ref SK/008128) at alt $412 \mathrm{~m}$ from layer of burnt wood and burnt flint at base of pit $30 \mathrm{~cm}$ deep in mineral soil, covered by stones and flint. Mesolithic flint waste surrounded pit in $15 \mathrm{~cm}$ sand over mineral soil, all buried below $60 \mathrm{~cm}$ peat. Excavated 1924 by F Buckley and stored in Tolson Mem Mus, Huddersfield, Yorkshire.

\section{Q-789. Warcock Hill, Marsden, Yorkshire}

$$
8606 \pm 110
$$

Burnt wood, oak and birch $\left(53^{\circ} 37 \mathrm{~N}, 1^{\circ} 57^{\prime} \mathrm{W}\right.$, Nat Grid Ref $\mathrm{SK} / 032098)$ at alt $365 \mathrm{~m}$ from Pit 5 dug into underlying shale and thin overlying gray sand on $\mathrm{N}$ side of Mesolithic workshop floor. Occurrence of peculiar gray banded flinty chert on floor and in pits suggested they 
were contemporary and dug during the occupation. Overlain by thin layer of peat. Excavated 1925 by F Buckley and stored in Tolson Mem Mus.

$5380 \pm 80$

3430 BC

Sandy charred wood fragments $\left(53^{\circ} 30^{\prime} \mathrm{N}, 1^{\circ} 48^{\prime} \mathrm{W}\right)$ from $23 \mathrm{~cm}$ depth in Mesolithic hearth in mineral soil separated by $15 \mathrm{~cm}$ sand from intact overlying peat $1 \mathrm{~m}$ thick. Assoc with Mesolithic flint artifacts. Coll 1963 by J Radley, Royal Comm for Historic Monuments. See Radley et al, 1974.

Q-800. Broomhead Moor, W Riding, Yorkshire $6623 \mathrm{BC}$

Small fragments of burnt wood $\left(53^{\circ} 25^{\prime} \mathrm{N}, 1^{\circ} 48^{\prime} \mathrm{W}\right)$ with fire fractured chert stratified $7.5 \mathrm{~cm}$ deep in sand beneath intact $1 \mathrm{~m}$ thick blanket bog peat layer. Assoc with Mesolithic flint artifacts. Coll 1963 by J Radley. See Radley et al, 1974.

Burnt wood $\left(53^{\circ} 18^{\prime} 30^{\prime \prime} \mathrm{N}, 1^{\circ} 12^{\prime} 22^{\prime \prime}\right.$ W, Nat Grid Ref SK/529794) fragments (Quercus) id by $\mathrm{R}$ A Jones Univ Sheffield, from Hearth 'B' in Mesolithic occupation site at Thorpe Common Rock Shelter, $2 \mathrm{~km}$ SE village of Thorpe Salvin, S Yorkshire. Coll Aug 1972 by P A Mellars, Univ Sheffield, partly 'in situ and partly during sieving of material from hearth'. Hearth 'B' (Baulk 21) occupies lower part of deposits and is stratigraphically earlier than Hearth 'A'. Sample was $30 \mathrm{~cm}$ below undisturbed surface and assoc with typical 'Geometric' industry.

\section{Q-1117. Thorpe Common Rock Shelter (II) 4666 BC}

Burnt wood (53 $18^{\prime} 30^{\prime \prime} \mathrm{N}, 1^{\circ} 12^{\prime} 22^{\prime \prime}$ W, Nat Grid Ref SK/529794) fragments found in situ near base of Mesolithic deposits (Baulk 15). Coll Aug 1972 by P A Mellars. Wood id as either Alnus or Corylus by $\mathrm{R}$ A Jones.

\section{Q-1118. Thorpe Common Rock Shelter (III) $\mathbf{3 7 3 0}$ вC}

Bone fragments $\left(53^{\circ} 18^{\prime} 30^{\prime \prime} \mathrm{N}, 1^{\circ} 12^{\prime} 22^{\prime \prime} \mathrm{W}\right.$, Nat Grid Ref SK/ 529794), some Red Deer (Cervus Elaphus), found immediately below large limestone block forming part of structure/wall at $\mathrm{N}$ end of site. Sample dates wall construction, unique in context of British Mesolithic, and latest occupation of the site (Baulk 15). Coll Aug 1972 by P A Mellars; id by G W Barker, Dept Ancient History, Univ Sheffield.

\section{Q-1127. Wetton Mill Rock Shelter, $\quad \mathbf{8 8 4 7} \pm 210$ Staffordshire \\ $6897 \mathrm{BC}$}

Collagen extracted from bone fragments $\left(53^{\circ} 06^{\prime} \mathrm{N}, 1^{\circ} 51 \mathrm{~W}\right.$, Nat Grid Ref SK/096563) from Wetton Mill Minor Rock Shelter, Manifold Valley, Staffordshire. Bones chosen for proximity to Mesolithic flint 
artifacts. Indications are present of lengthy occupation of shelter from late glacial times to Bronze age. Coll 1967 to 1973 by J H Kelly, City Mus Hanley, Stoke on Trent, Staffordshire. See Switsur (1974c).

\section{The Udal series}

Excavations over 10 seasons at The Udal, $4 \mathrm{~km}$ NE from Sollas on the Ard a' Mhorain peninsula, N Uist, Outer Hebrides $\left(57^{\circ} 38^{\prime} \mathrm{N}\right.$, $7^{\circ} 12^{\prime} \mathrm{W}$, Nat Grid Ref NF/824783) showed probable continuous occupation of area during preceding 4000 yr to ca 17th century AD. Site, Coileagan an Udail, (Sandhills of Udal), consists of 4 main dunes rising, with nearly vertical sides, $12.3 \mathrm{~m}$ from the machair plain. Outer Hebrides machair is a plain $160 \mathrm{~km}$ long of shell-sand forming $\mathrm{W}$ littoral of the Outer Isles. Despite considerable fluctuations of area in historic and prehistoric times, with its high lime content and ease of cultivation, it has been important for early settlement in Scotland as many sites indicate. At The Udal thick clay was deposited on a rock escarpment, where, in black earth, the earliest settlements took place. Subsequently, massive drifts of machair accumulated on this foundation suitable for later prehistoric settlement. On $\mathrm{E}$ of escarpment a large sand plateau built up, a foundation for further settlement. Erosion has left the area dispersed into isolated 'tells' and extreme sand blow in the 17th century caused final evacuation of site. Further erosion threatened the sites thus preserved in the machair. Excavations revealed at least 46 levels relative to 18 stratigraphic phases. Many artifacts were found, including shell (marine and terrestrial), bone (human, animal, and fish) with much pottery at all levels. A multi-disciplinary scientific study is being made in excavations.

The present series is part of a collaboration between I A Crawford and V R Switsur, Univ Cambridge, in determining main chronologic framework of site by radiocarbon dating. Samples of assoc pottery were coll to be dated by co-worker $\mathrm{H}$ McKerrell, using thermoluminescence to establish an independent absolute chronology and also a detailed comparison of the ${ }^{14} \mathrm{C}$ and $\mathrm{T} 1$ time scales over a 4000 -yr period.

Q-1131. The Udal (40)

$1614 \pm 120$

Collagen extracted from vertebrum of whale (Mesoplodon Sowerbiensis) from Level XIII which contains Norse artifacts.

Q-1132. The Udal (39)

$1353 \pm 115$ AD 597

Collagen extracted from bones of lamb and calf from inhumation beneath floor of building at Level $\mathrm{X}_{0}$.

Q 1133. The Udal (5)

$3466 \pm 120$ $1516 \mathrm{BC}$

Shell (unid) from Level $\mathrm{X}_{3}$ containing Beaker type pottery. Date measured on $\mathrm{CO}_{2}$ released from shell carbonate by dilute acid. 
Q-1134. The Udal (20)

$3564 \pm 100$

Collagen extracted from animal bones (unid), from Level $\mathrm{X}_{3}$ contemporary with Q-1133.

Q-1135. The Udal (35)

AD 1038

$912 \pm 150$

Wood charcoal from Level $\mathrm{N}_{\mathrm{IXc}}$ obtained by sieving mixed materials after excavation.

Q-1136. The Udal (34)

$1091 \pm 40$

Collagen extracted from pelvic bone of whale found in Level $\mathrm{N}_{\mathrm{X}}$, contemporary with Norse artifacts.

Q-1137. The Udal (38)

$1502 \pm 80$

Collagen extracted from vertebrum of whale (Balarna Glacialis) found in Levels $\mathrm{N}_{\mathrm{XI}}$ and $\mathrm{N}_{\mathrm{XII}}$. This dates pre-Norse artifacts.

Q-1138. The Udal (36)

$853 \pm 40$

Wood charcoal from Level $\mathrm{N}_{\mathrm{IXe}}$ containing Norse artifacts.

Q-1139. The Udal (37)

$1271 \pm 115$

Wood charcoal from Level $\mathrm{N}_{\mathrm{Xb}}$ assoc with pre-Norse artifacts.

General Comment: dates agree well with expected chronology of site and form a framework for dating other sites in Outer Hebrides and W Highlands of Scotland. For full discussion of chronology, see Crawford \& Switsur, 1975. Comparison with thermoluminescence measurements will also be made.

\section{Q-761. Sands of Forvie, Aberdeenshire}

$2602 \pm 115$

Carbonized wood fragments (oak) from prehistoric village site $\left(57^{\circ}\right.$ $\left.18^{\prime} \mathrm{N}, 1^{\circ} 57^{\prime} \mathrm{W}\right)$. From post hole of Hut E. Probably preserved by early waterlogging of site, which yielded much 'flat-rimmed' pottery, a widespread type of Scottish material as yet not properly dated.

\section{Q-870. Holme Pierrepont, Nottinghamshire}

$304 \pm 70$

Wood from brushwood layer of wooden structure of sharpened oak stakes, possibly part of flood bank. Found during gravel digging on $\mathrm{S}$ side of R Trent, Holme Pierrepont, Nottinghamshire $\left(52^{\circ} 57^{\prime} \mathrm{N}, 1^{\circ} 05^{\prime}\right.$ W, Nat Grid Ref SK/628399), overlying gravel, covered by $1.5 \mathrm{~m}$ silts and sands to present flood-plain surface. Excavated by M Ponsford and 
A MacCormick, Nottingham Mus. Subm 1967 by H Godwin. Comment: confirms expected date of Medieval or later.

Q-1164. Ely Cathedral West Tower

$835 \pm 40$

Portion of timber tie, oak, embedded in $275 \mathrm{~cm}$ thick masonry ca $36.6 \mathrm{~m}$ above ground level in $\mathrm{W}$ tower of Ely cathedral, Ely, Cambridgeshire (52 23' 39" N, $0^{\circ} 15^{\prime} 20^{\prime \prime}$ E, Nat Grid Ref TL/541802). Specimen covered by $15 \mathrm{~cm}$ masonry. Timber may have been inserted at time of original building or later to correct chronic distress in 13th, 15th, or 18th centuries. Coll June 1973 by J Heyman, Engineering Dept, Univ Cambridge. Comment: conventional dates for construction of $\mathrm{W}$ tower bracket AD 1107 to 1189; sample age agrees.

\section{Q-1196. Denny Longbow, Falkirk}

$3250 \pm 75$

Oak wood from remains of longbow found in peat at Denny, Falkirk, Stirlingshire in $1889\left(56^{\circ} 1^{\prime} \mathrm{N}, 4^{\circ} 5^{\prime} \mathrm{W}\right.$, Nat Grid Ref NS/768832) by A Frew and stored in Falkirk Mus. Sample coll by R W Feachem, Ordnance Survey; wood id by C A Dickson, Quaternary Research, Univ Cambridge. Comment: 1 of 5 bows from Britain; see Q-646: $4640 \pm$ 120; Q-598: $4615 \pm 120$; Q-684: $3680 \pm 110$; Q-669: $3270 \pm 110$, but Denny longbow is unique in Europe, being made from oak wood. See Switsur (1974b).

Q-1163. Washingborough Fen, Lincolnshire

$2253 \pm 80$

303 BC

Birch wood from charred post $\left(53^{\circ} 14^{\prime} \mathrm{N}, 0^{\circ} 27^{\prime} \mathrm{W}\right.$, Nat Grid Ref $\mathrm{TF}_{/}^{\prime}$ 042713) at junction of peat layers overlain by shelly deposit containing iron-age pottery, and human and animal bone at depth of $75 \mathrm{~cm}$ below present surface. Coll April 1973 by J M Coles. Comment: precisely dates Iron age wares in area otherwise devoid of such occupation debris.

\section{Q-1173. Red Hill, Osea Road, Maldon, Essex \\ $2130 \pm 40$}

Carbonized wood, remains of single small branch from 'Red Hill' Osea Road, Maldon (51 $43^{\circ} \mathrm{N}, 0^{\circ} 41^{\prime} \mathrm{E}$, Nat Grid Ref TL/887075), 1 of several 'Red Hills' on SE coast of England; remains of Roman or pre-Roman sites, where extensive salt making occurred. Sample presumably fuel for evaporation process. Few such sites have been explored adequately and precise age is doubtful despite range of assoc coarse pottery. Coll autumn 1972 during excavation by Colchester Archaeol Group. Subm by $\mathbf{K}$ de Brisay. Comment: site was probably used for long period and radiocarbon date is 1st independent age estimate of this industrial activity. Cf De Brisay (1973) and Switsur (1974a). 


\section{B. Miscellaneous}

\section{Rio Ambi Valley, Ecuador series}

During building excavations in April 1957, on right bank of Rio Ambi, for new Otavalo electricity power sta, Imbabura Prov Ecuador $\left(0^{\circ} 15^{\prime} 55^{\prime \prime} \mathrm{N}, 78^{\circ} 16^{\prime} 26^{\prime \prime} \mathrm{W}\right)$, alt $2450 \mathrm{~m}$, a fossilized human skeleton, in hunched semi-upright position was found by a workman, C Baca. Remains, from youngest of 4 fluvial terraces, were encased in coarse tuff cemented with calcium carbonate and stained with iron compounds from ground water. Bone cavities filled with calcium carbonate, interior of skull lined with thick adherent layer of aragonite crystals. Skeleton was in irregular cavity $65 \mathrm{~cm}$ high by $30 \mathrm{~cm}$, possible a collapsed cave, at junction of alluvium and tuff ca $6 \mathrm{~m}$ above river.

Remains may be important for Ecuadorian prehistory, but distortion of skull from overlying deposits and heavy encrustation precluded definite age decisions on anthropologic grounds. Sample coll from mus 1971; subm by D M Davies, Dept Zool, Univ College, London.

\section{Q-1032. Otavalo cranium, aragonite $\quad 27,073 \mathrm{BC}$}

Aragonite crystalline deposit from interior lining of skull.

\section{Q-1033. Otavalo cranium, bone $\quad \mathbf{2 6 , 0 6 2} \mathrm{BC}$}

Mainly bone from crushed base of skull mixed with interstitial calcium carbonate.

General Comment: in each case $\mathrm{CO}_{2}$ measured was evolved from sample by diluted mineral acid under reduced pressure. No collagen was recovered from remains. Dates agree with thermoluminescence date obtained by J H Fremlin, Dept Applied Radioactivity, Univ Birmingham, of $25,000 \pm 3000 \mathrm{yr}$ on aragonite crystals from interior of skull. This presumably dates crystal structure of the aragonite, laid down subsequently to death, and is independent of its chemical nature. Dates also agree with those of Univ Birmingham radiocarbon lab (Shotton \& Williams, 1973) on similar material (Birm-331: 27,100 \pm 700; 35,000

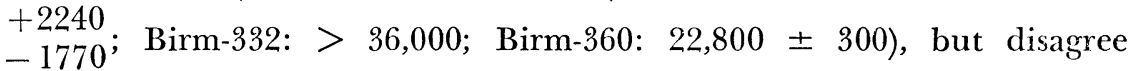
with their dates on organic extract (Birm-331: $2300 \pm 270$; Birm-360: $2670 \pm 150)$. Carbonate measured could be largely of magmatic origin.

\section{Q-1165. Upper Mashai peat}

Peat from depth $2.5 \mathrm{~m}$ from lowest of 5 peat layers in sec $3 \mathrm{~m}$ deep, Mashai $\left(29^{\circ} 41^{\prime} \mathrm{S}, 29^{\circ} 5^{\prime} \mathrm{E}\right) \mathrm{E}$ Lesotho, Africa. Date needed to compare with others in area for stratified industrial assemblages in Lesotho. Coll 1971 by P L Carter, Dept Archaeol \& Anthropol, Univ Cambridge. Cf Carter (1972; 1974). 


\section{Q-1122. Csepel Island, Budapest}

Charcoal fragments under ancient soil profile underlying dune of blown sand $\left(47^{\circ} 25^{\prime} \mathrm{N}, 10^{\circ} 5^{\prime} \mathrm{E}\right)$ in pit 2, Hollandi St, Csepel Island, Hungary, between 2 arms of R Danube just $S$ of Budapest, $200 \mathrm{~m}$ from river on $4 \mathrm{~m}$ terrace. Dated to establish beginning of Eneolithic-earliest Bronze age in E Central Europe and date for Bell Beaker culture. Coll Aug 1972 by $\mathrm{N}$ Kalicz. Subm by J M Coles and S J Shennan, Dept Archaeol \& Anthropol, Univ Cambridge.

\section{REFERENCES}

Butzer, K W, Isaac, G L, Richardson, J L, and Washbourn-Kamau, C, 1972, Radiocarbon dating of East African lake levels: Science, v 175, p 1069-1076.

Carter, P L, 1972, Moshebi's Shelter: Lesotho, v 8, p 13-23.

1974, Dating of stratified industrial assemblages in E Lesotho: in press.

Coles, J M, Hibbert, F A, and Orme, B J, 1973, Prehistoric roads and tracks in Somerset, England, pt 3, Sweet Trackway: Prehist Soc Proc, v 39, p 256-293.

Crawford, I A and Switsur, V R, 1975, Chronology of Coileagean An Udail: Antiquity, $\mathrm{mss}$ in preparation.

De Brisay, K, 1973, Excavation of a Red Hill at Osea Road, Maldon, Essex: Colchester Archeol Group Bull, v 15, p 27-28.

De Vries, H1, Stuiver, M, and Olsson, I, 1959, a proportional counter for low level counting with high efficiency: Nuclear Instruments \& methods, v 5, p 111-113.

Durno, S E and McVean, D N, 1959, Forest history of the Beinn Eighe Nature Reserve: New Phytologist, v 58, p 228-236.

Fontes, J C, Moussie, C, Pouchan, P, and Weidmann, M, 1973, Humid phases in the Upper Pleistocene and Holocene in S Africa: Acad sci [Paris] Comptes rendu, v 277, p 1973-1976.

Grove, A T and Goudie, A S, 1971, Late Quaternary lake levels in the rift valley of S Ethiopia and elsewhere in tropical Africa: Nature, v 234, p 403-405.

Godwin, Harry, 1964, Late Weichselian conditions in south eastern Britain; organic deposits at Colney Heath, Herts: Royal Soc [London] Proc, ser B, v 160, p 258.

Hegde, K T M and Switsur, V R, 1973, Radiocarbon dates of the buried soil in the lower Narmada Valley: Current Sci (India), v 42, p 607-609.

Hibbert, F A, Switsur, V R, and West, R G, 1971, Radiocarbon dating of Flandrian pollen zones at Red Moss, Lancashire: Royal Soc [London] Proc, ser B, v 177, p $161-176$.

Leamy, M L and Rafter, T A, 1972, Isotope ratios preserved in pedogenic carbonates and their application in palaeopedology: 8th Internatl conf radiocarbon dating, Proc, Lower Hutt, New Zealand, v 1, p D42-D57.

Lee, A J and Tallis, J H, 1974, Regional and historical aspects of lead pollution in Britain: Nature, in press.

Lewis, F J, 1905-7, 1911, The plant remains in the Scottish peat mosses: Royal Soc [Edinburgh] Trans, v 41, p 699-723; v 45, p 335-360; v 46, p 33-70; v 47, p 793-833.

Radley, J, Switsur, V R, and Tallis, J H, 1974, The excavation of three "Narrow Blade" Mesolithic sites in the Southern Pennines, England: Prehistoric Soc Proc, in press.

Rafter, T A, 1970, The dating of fossil man in Australia: Internatl symposium on hydrogeochem \& biochem, Proc, Tokyo, Japan.

Rightmire, C, 1967, A radiocarbon study of the age and origin of caliche deposits: MA thesis, Univ Texas.

Shotton, F W and Williams, R E G, 1973, Birmingham University radiocarbon dates VII: Radiocarbon, v 15, p 451-468.

Switsur, V R, 1972, Combustion bombs for radiocarbon dating: 8th internatl conf on radiocarbon dating, Proc, Lower Hutt, New Zealand, v 1, p B11-B23.

1974a, Report on the radiocarbon dating of the Red Hill, Osea Road, Maldon, Essex: Colchester Archaeol Group Bull, v 17, p 43-44. 
1974b, Dating the prehistoric longbow from Denny, Scotland: Antiquity, v 48, p 56-58.

1974c, Radiocarbon dating the Mesolithic deposits at Wetton Mill Rock Shelter: Stoke on Trent Mus Archaeol Soc rept no. 8, in press.

Switsur, V R, Hall, M A, and West, R G, 1970, University of Cambridge natural radiocarbon measurements IX: Radiocarbon, v 12, p 590-598.

Switsur, V R and West, R G, 1973, University of Cambridge natural radiocarbon measurements XII: Radiocarbon, v 15, p 534-544.

Wade-Martins, Peter, Fletcher, John, and Switsur, Roy, 1973, North Elmham; the dating: Current Archaeology, v 4, p 22-28.

Wainwright, G J, 1964, The pleistocene deposits of the lower Narmada river: Maharaja Sayajirao Univ, Archaeol \& Ancient History, ser 7, Baroda, India.

Williams, G E, and Polach, H A, 1971, Radiocarbon dating of arid zone calcareous palaeosols: Geol Soc America Bull, v 82, p 3069-3086. 